\title{
SELF-EMPLOYMENT OF WOMEN THROUGH ASSOCIATIONS IN THE RURAL AREAS OF SIRINICKA ZUPA
}

\author{
Goran Maksimović ${ }^{1}$, Tatjana Ivanović2 , Aleksandra Vujko ${ }^{3}$ \\ *Corresponding author E-mail: goran.maksimovic@pr.ac.rs
}

A R T I C LE I N F O

Review Article

Received: 28 December 2018

Accepted: 14 March 2019

doi:10.5937/ekoPolj1901251M

UDC 331.57-055.2:316.334.55

(497.115 Sirinićka župa

Keywords:

rural tourism, self-employment, the associations for the empowerment of women

JEL: J16, J21
A B S T R A C T

In order to empower and become independent in their tending, women have established the associations (the associations for the empowerment of women - AEW). Women in these associations have becoming aware that, if they had performed united, they could radically change their personal lives, their families' lives, as well as of the communities they have lived in. Therefore, the associations can play a role of giving a woman "a chance" to be independent both in the economic and social sense. This paper aims to show effects of the women's empowerment in rural areas, i.e. the influence of the AEW on the female entrepreneurship and self-employment. Empirical research was done on a free sample of 420 women from 10 villages in the Serbian enclave Sirinicka Zupa in Kosovo and Metohija by the personal communication technique, i.e. using a questionnaire. The results analysis shows a unique formula for the empowerment of women: self-employment as a goal for the women's empowerment depends directly from the motive for starting a business $(25 \%)$, business environment (20.24\%), as well as the support of AEW (54.76\%).

(C) 2019 EA. All rights reserved.

\section{Introduction}

Social systems and cultures interpret the biological differences between women and men in different ways and sum them up into the sets of social norms in form of desirable and

1 Goran Maksimović Ph.D., Associate Professor, University of Priština, Faculty of Agriculture, Kopaonička Street nn, 38219, Lešak, Serbia, Phone: +381 63 419 757, E-mail: goran.maksimovic@pr.ac.rs

2 Tatjana Ivanović Ph.D., Assistant Professor, University of Priština, Faculty of Agriculture, Kopaonička Street nn, 38219, Lešak, Serbia, Phone: +381 66005 605, E-mail: tatjana.ivanovic@pr.ac.rs

3 1) Novi Sad Business School (Vladimira Perića Valtera 4, 21000 Novi Sad, Serbia, Tel. 003816491426 45,e-mail: aleksandravujko@yahoo.com)

2) South Ural State University, Institute of Sports, Tourism and Service, (76 Lenin Ave, Chelyabinsk 454080, Russia)

3) University of Business Studies, Faculty of Tourism and Hotel Management (Jovana Dučića 23a, Banja Luka 78000, Republic of Srpska) 
acceptable activities and behaviours. The social institutions, social norms, social customs and laws, as well as the economic institutions (the job market and similar) shape the relations and the social models of behaviour, the share of roles between women and men, and in that way determine a range of rights and possibilities the specific groups dispose with (Vujko, Maksimovic, 2018). Today labour market characterize rising an automated jobless society (Grossman, 2018), job displacement caused by workplace automation (Sorells, 2018), or digital labor market (González, 2018) and generaly automation will transform the labor market (Chessell, 2018) which means that consumers facing varying product offer from different countries (Šapić et al., 2018).

Theoretically, women can get a chance to realize themselves, but only in case if their total status is improved. This type of the status improvement is called "the women's empowerment". The women's empowerment is one of the most important issues in the process of the emancipation of women (Agarwal, 1997). "The empowerment of women is the process in which women become active independently and collectively, have more knowledge and become the target-oriented active participants, who undertake/ support the initiatives for overcoming the gender inequalities" (Rao, 2011). Therefore, the empowerment of women starts the strategy for the achievement of gender equality (Floro-Maria, 1995; Reddy et al., 2003).

The empowerment of women has been mostly expressed through different forms of the women's associations (the associations for the empowerment of women - AEW). Such associations provide women to have greater control over their lives (Hashemi et al., 1996; Orser et al., 2006). Membership in these associations gives women "the ability to see and to be seen", and also provides them the feeling of control over their lives. The AEW focuses on improving skills, innovativeness, the approach to financial institutions for the micro enterprises/projects, introduction of savings and credit control for economically poor, mainly rural areas (Vujko, Maksimovic, 2018).

During the past two decades the issue of the women's empowerment has developing (Kabeer, 2005; Narayan, 2002). Three interconnected dimensions for the empowerment of women are: 1) Approach to resources, including preconditions; 2) Agencies, including processes; and 3) Achievements, including outcomes (Kabeer,2005). It is important to know that "the empowerment of women" the most often starts by trying to understand how and why women have been "non-empowered" (Bhatt-Datta, Gailey, 2012). The empowerment of women means "giving women the right to make choices in their lives and influencing change and ability that a woman controls her life over the key material and non-material resources" (Moser,1991).

"Social welfare, self-estimation and independence in combination with the aspiration or achievement of economic independence" defines the empowerment of women (Osirim,2001). Regarding further considering of the definition of this term, we can conclude that the empowerment of women is a process through which women get greater control over their lives (Seguino, 2000; Soroushmehr et al., 2012). It means also more self-confidence and ,the spine“ for their ideas and creativity (Batliwala, 
1994). The empowerment has four aspects: first, in order a woman to be empowered, she has to be "free"; second, the empowerment cannot be achieved by a third person, but directly, from the inside; third, the definitions of empowerment usually include a subjective attitude of people who make decisions on the important issues in their lives and are capable to implement them, and finally, the empowerment is the process that takes place, and not a stagnant product (Mosedale,2005). Dimensions of the women's empowerment include: a sense of self-confidence and a vision of the future, mobility and visibility, economic security, making decisions in a household, ability of more efficient interaction in the public sphere and the participation in non-family groups. There is a general attitude that the empowerment of women is a course that manifests in several directions (Hashemi andShuler,1993).

One of the most important forms of the term is absolutely the welfare of women, where the empowerment of women is considered the process of women's and girls' prosperity improvement (Ali, Hatta, 2012). Finally, the conclusion can be drawn that the empowerment of women is defined as the achievement of "unwritten rules" including: education, economic self-confidence, ownership and the inheritance of property, political participation and the elimination of all forms of discrimination concerning the gender, violence and abuse, harassment and exploitation (Harriet, Sen, 2003).

\section{The meaning of the female entrepreneurship and self-employment}

The field of entrepreneurship increases its theoretical focus to the unique contribution of women to business and society (De Bruin et al., 2006; 2007). The female entrepreneurship is a multi-dimensional phenomenon that can be approached from various aspects: From the female activism point of view, when it is considered a way to activate female resources in favour of women (Calás et al., 2009); from the economic development aspect, when it is treated as a way to activate female resources, especially in the field of small and medium enterprises (Heilman, Chen, 2003; Hania et al., 2012); from the social policy point of view, when tries to decrease the women's unemployment by strengthening the women's entrepreneurship, especially middle-aged women, who have been exposed to a great risk of losing a job during the transition (Godwyn, 2009); from the aspect of providing the sustainable development - the female entrepreneurship can be a way to harmonize the economic development with the ecological and social development, through the socially responsible business (Markantoni, Van Hoven, 2012).

Analysts ask questions why the micro-financing programs are more affecting women, as well as why women are not treated the same as men (Tassel, 2004). International donations, governments and other experts for development pay more attention to microfinancing as a strategy that could reach women and engage them in the developmental process (Ali, Hatta, 2012). The women's entrepreneurship has mostly been viewed from the social welfare point of view, although it has been essentially "par excellence" individual strategy of the women's emancipation. Every woman who decides to be an entrepreneur, or is an entrepreneur, at the same time a self-realized, self-aware and selfstrengthened woman. 


\section{The situation in Serbia}

Serbian society can be described as patriarchal. In this environment, women often lose their self-confidence and become victims of the social "silent violence" (Ramanathan, 2004). In these cases, the entrepreneurship and self-employment can empower women and help them feel important and useful (Calás et al., 2009; Bhatt-Datta, Gailey, 2012). The female entrepreneurship in Serbia had been mentioned for the first time in the first half of ' 90 ies of the $20^{\text {th }}$ Century, through the supporting programs of international institutions that have aimed to include women refugees faster economically and socially. Education for these women had been organized aiming to raise awareness on self-employment, especially on the independent trade shops and trades, in order women to become entrepreneurs and insure their families. In the last 10-15 years things have been gradually changing. The number of women's enterprises has increased, while the structure has changed, so besides the exclusively "female" jobs, women have become visible in other fields such as providing various services, bookkeeping, intellectual services (financial consulting, managing human resources, education) etc. Rural tourism has become particularly interesting.

Rural tourism in Serbia is a new phenomenon in which farmers and people who live in rural areas search for some alternative sources of income (Vujko et al. 2016; Petrović et al. 2017). Enterprises engaged in rural tourism have been connected to a local regional community through the procurement of materials (raw materials and finished products), business services and employment (Ateljevic 2009). Some rural households are on agricultural land, and the owners rarely stop their work while being engaged in rural tourism. The others, more common type is the rural households that aren't engaged in agriculture, which can point out to a fact that agriculture is not a necessary factor for growth and development of rural settlements. It is considered that especially rural tourism provides women a chance to upgrade themselves through self-employment (Vujko et al. 2017).

\section{The research methodology}

\section{The area of research}

In the Serbian enclave Sirinicka Zupa in Kosovo and Metohija lives around 13000 nonAlbanian population, prevalently of Serbian nationality, and it is located on $250 \mathrm{~km}^{2}$ with one urban and fifteen rural settlements. It is the mountain area with the specific jagged entirety and the altitude range from $900 \mathrm{~m}$ in the Lepenac valley to $2500 \mathrm{~m}$ at the highest peak Ljuboten on Sar-mountain. Altitude and climatic conditions show that the area of Sirinicka Zupa is extremely suitable for the development of livestock breeding, fruit and crop growing, as well as for the development of rural tourism. In the structure of agricultural land of Sirinicka Zupa prevails: pastures (38.8\%), meadows (25\%), which means that this area is favourable for the development of livestock breeding, especially the organic sheep and goat breeding. Putting the existing cheese factories in function, as well as by organizing the supply of population with the registered herds 
of sheep and goats, the preconditions for the production of high-quality dairy products could be created, and also the possibility for making the Sar-cheese brand, well-known by its quality throughout ex-Yugoslavia.

\section{Sources of data and the methods of research}

Research was conducted in September and October 2018 on a sample of 420 women in 10 rural areas in Kosovo and Metohija in Sirinicka Zupa. In this paper was explored an effect of the AEW on women's entrepreneurship and self-employment. The empowerment concepts have the overlapping dimensions, especially in the context of the female entrepreneurship and self-employment. The paper was trying to come to a formula for the women's empowerment, i.e. was using the research results to obtain data in order to support female members of the AEW to start their own enterprise and self-employ. The associations should be established aiming to empower women of different ages within the associations, as in economic as well as in social sense, to be engaged in humanitarian work and activities in the field of culture and folk art (making handicrafts and food products, as well as souvenirs). They should take part in country parties, fairs and other events related to food preparation (cooking) and other products of the female folk art. All interested female respondents in the observed villages were taking part in this research. The only condition was to have a domicile address in these villages. Research of a target group was done by interviewing (using the ,face to face“ technique), by applying a questionnaire. Results of the survey were shown in the table.

It was necessary to answer some questions and set up certain sub-hypothesis aiming to test an initial $\mathrm{X}$ hypothesis that self-employment is the final goal of the women empowerment and to establish what would be an adequate stimulus for women to start their own enterprise (setting a formula). One of the most important questions that should be answered are: which factors affect the women's empowerment? In order to answer the question, 3 sub-hypotheses were set: $\mathrm{x} 1$ - the motive ,unemployment and dissatisfaction with the previous job" mostly affect the women's empowerment for starting own business; $\mathrm{x} 2$ - lack of an initial capital as a part of the business environment have most effect on the women's empowerment for starting own business; and x3 support of the AEW strongly affects the female empowerment. Besides a question if some of these factors have an effect on the empowerment, this paper was focused on the importance of influence, if it was present. The focus was on the AEW support to the women's empowerment. In order to check the x 3 sub-hypothesis, it would be necessary to set several more sub-hypotheses: $\mathrm{x} 4$ - members of the AEW have been empowered; $\mathrm{x} 5$ - members of the AEW have been empowered for starting their own business in the field of rural tourism, the production of cheese from Sar-mountain, the production of medicinal herbs; $x 6$ - the greatest significance of the AEW is in the informationfinancial support (Vujko, Maksimovic, 2018).

The study tried to measure the women's empowerment. Exactly 420 women were interviewed for this study, and their qualitative answers were providing a base for drawing some conclusions (Eisenhardt, Graebner, 2007). These scores of assessments 
and the evaluation of results were used for further analysis (Calás et al. 2009; BhattDatta \& Gailey, 2012). After the conducted survey analysis, there has come to a conclusion on the role of the AEW and the female empowerment to self-employment.

\section{Results and discussion}

As for the age structure, the highest percentage of female respondents (197) $47 \%$ is in the age group between 20 and 50 years, and then in the group from 51 to 70 (29) 7\%. The most of female respondents (248) $59 \%$ has only the secondary school education, 80 of them (19\%) has the university education, $59(14 \%)$ are college educated, and 33 women $(8 \%)$ is with the elementary school education. Data related to the family and parental status of women and was processed in this paper. The research has shown that 256 women (61\%) have been married, 113 women $(27 \%)$ have been in extramarital community, 38 women (9\%) have been divorced, and $13(3 \%)$ have been widows. At the same time, the research showed that 366 women $(87.14 \%)$ were mothers, while 54 women (12.86\%) didn't got children.

Table 1 - Results of an interview

\begin{tabular}{|c|c|c|}
\hline \multicolumn{3}{|c|}{ Enclosure 1 - What would motivate you to establish your own enterprise? } \\
\hline & Frequency & Percent \\
\hline Taking care of others & 126 & 30 \\
\hline Quest for achievements & 13 & 3 \\
\hline A higher degree of freedom and independence & 29 & 7 \\
\hline $\begin{array}{l}\text { Unemployment, dissatisfaction with the previous job (workplace, } \\
\text { associates, work conditions) }\end{array}$ & 231 & 55 \\
\hline Something else & 21 & 5 \\
\hline Total & 420 & 100.0 \\
\hline \multicolumn{3}{|c|}{ Enclosure 2 - How do you see the business environment in Sirinicka Zupa? } \\
\hline Women have more responsibilities in families and the education of children & 50 & 12 \\
\hline The problem lies in lack of an initial capital & 336 & 80 \\
\hline Unfavourable attitude of society for a woman who starts a new business & 21 & 5 \\
\hline Problem of marginalization, humiliation of women and sexual harassment & 0 & 0 \\
\hline $\begin{array}{l}\text { Deficiencies as the results of a high level of corruption and the strong male } \\
\text { network }\end{array}$ & 13 & 3 \\
\hline Укупно Total & 420 & 100.0 \\
\hline \multicolumn{3}{|c|}{ Enclosure 3 - Would you feel more empowered as a member of the AEW? } \\
\hline Yes & 399 & 95 \\
\hline No & 8 & 2 \\
\hline I don't know & 13 & 3 \\
\hline Total & 420 & 100.0 \\
\hline
\end{tabular}

Source: own research 
Table 2 - The interview results

\begin{tabular}{|c|c|c|}
\hline \multicolumn{3}{|l|}{ Enclosure 4 - In which areas is the strongest empowerment? } \\
\hline Humanitarian work and the care for a local community & 0 & 0 \\
\hline Preparation and production of a cheese from Sar-mountain & 147 & 35 \\
\hline Traditional trades and handicrafts & 0 & 0 \\
\hline Ecology and environment & 0 & 0 \\
\hline Rural tourism & 244 & 58 \\
\hline Agricultural activities: the products made of (medicinal) herbs & 29 & 7 \\
\hline I don't feel any empowerment & 0 & 0 \\
\hline Total & 420 & 100.0 \\
\hline \multicolumn{3}{|c|}{ Enclosure 5-Would you start a new business and what business would you do? } \\
\hline I would like to produce the embroidered materials & 0 & 0 \\
\hline I would like to make souvenirs & 0 & 0 \\
\hline I would like to deal with weaving and crochet & 0 & 0 \\
\hline I would like to produce jewellery & 0 & 0 \\
\hline I would like to deal with the production of cheese from Sar-mountain & 147 & 35 \\
\hline I would like to make the plant products & 29 & 7 \\
\hline I would like to deal with the rural tourism & 244 & 58 \\
\hline No & 0 & 0 \\
\hline Total & 420 & 100.0 \\
\hline \multicolumn{3}{|l|}{ Enclosure 6 - What is the key role of the AEW? } \\
\hline Organizing meetings, trade fairs and other manifestations & 13 & 3 \\
\hline Taking part in projects & 0 & 0 \\
\hline Providing info on credits and the other forms of financing & 273 & 65 \\
\hline Providing documentation necessary for starting a new business & 0 & 0 \\
\hline Empowerment through education and the organization of forums & 8 & 2 \\
\hline The possibility of joint sale on the market & 126 & 30 \\
\hline I don't know & 0 & 0 \\
\hline Укупно Total & 420 & 100,0 \\
\hline
\end{tabular}

Source: own research

In the table no.1 and the enclosure no.1 can be seen that the most explored motive for starting the women's own business was the motive ,unemployment, dissatisfaction with the previous job ", which have meant that women entered entrepreneurship in order to do something for their selves and their families, unemployment, dissatisfaction with the previous job (55\%). The care of others motive was the ground for starting their own business for $30 \%$ of female respondents. Besides the financial motivation, the motivation related to self-realization was also very important (Dur, Glazer, 2008), i.e. proving their own abilities (a higher degree of freedom and independence $-7 \%$ ). Unlike the previous motive with the focus on the desire to make a profit in order to help the others, this motive is a driving power for women to achieve the human essence. Self-realized people are "what they really are", and not what they possess. Hence, everything previously said had confirmed the sub-hypothesis $\mathrm{x} 1$ that the motives 
"self-employment and the care for their families" are the main motives that affect the women's empowerment for starting their own business. According to the statements of women who helped in realizing this research, the motives in their decision whether or not start their own business have participated proportionally with $25 \%$.

\section{Business environment}

The research has shown that women haven't got enough information on credits, even the other information necessary for starting own business. Generally, only a number of women had their personal assets to invest in a new business. This is the reason why women have a great interest in the possibilities of various types of support and assistance, which have occurred in institutions such as the AEW. The research has shown that women have many obstacles for the development of their own businesses, and all these obstacles have proved to be the typical problems for women in business (Shabbir, Di Gregorio, 1996; Heilman, Chen, 2003).

The table no.1 and the enclosure no.2 show that the business environment has a significant effect on starting own business in several ways. The first example is the lack of financial resources to run a larger business $(80 \%)$. The second circumstance is the fact that women in Sirinicka Zupa still have major obligations in families and raising children $(12 \%)$. The third circumstance in an unfavourable attitude of the society about a woman who is starting her own business (5\%). This is more important reason for women from smaller communities, where this obstacle is more expressed. Disadvantages lie in the high level of corruption and strong male networks (3\%). All of these data prove the sub-hypothesis $\mathrm{x} 2$ that the lack of an initial capital, as a part of the business environment, strongly affect the women's empowerment for starting their own businesses. According to the women's statements, who helped in realizing this research, the business environment participates with the percentage of $20.24 \%$ in their decision whether to establish their own enterprise or not.

\section{Support of the $A E W$}

The AEW suggests jobs to women, but primarily jobs related to the manual production: weaving, crochet, embroidery, making jewellery, figurines and gypsum fridge magnets, drying plants for tea, making cookies, etc. After the association approves the business, they have one third of joint financing. The associations neither have offices nor the assets at the moment; the members of the association meet and work in houses of other members. They know better and support each other. It is noticeable almost family relations among members of the associations. The benefits of such relations are the opportunity for the collective identification of women and the exchange of individual experiences.

The table no. 1 and the enclosure no. 3 point out to the fact that even $95 \%$ women considered themselves very empowered as the AEW member. This data has confirmed the sub-hypothesis $\mathrm{x} 4$ that the AEW female members have been empowered. The table no. 2 and the enclosure no. 4 show that the women's empowerment within the $\mathrm{AEW}$ is the most intensive in the field of rural tourism $(58 \%)$, the production and 
preparation of cheese from Sara-mountain (35\%), and the agricultural activity: products made of herbs $(7 \%)$. This information is very important, while it points out to those opportunities, which women can use the most in the process of self-employment (Swanson, Timothy, 2012). Data from the table no.2 and the enclosure no.5 are proving the above mentioned, i.e. they show that even $58 \%$ of women would be engaged in rural tourism, while $42 \%$ of women would start their own business in the field of agricultural activity: the production of cheese from Sara-mountain, the production of medicinal herbs, etc. These data confirm the sub-hypothesis $x 5$ that the AEW members have been empowered for starting own business in the field of rural tourism and the agricultural production. The table no. 2 and the enclosure no. 6 show the role of the AEW in the women's empowerment. The members of AEWs consider these institutions as the stronghold where they can get the adequate information and financial support for starting their business $(65 \%)$. It is very important considering that it relies on the sub-hypothesis 2 (Table 1 and Enclosure 2). Hence, herewith was confirmed the hypothesis $x 6$ that the greatest significance of the AEWs was exactly in the information and financial support. The sub-hypothesis $\mathrm{x} 3$ (the support of the AEWs have an effect on the women's empowerment) was also confirmed by confirming the sub-hypotheses $\mathrm{x} 4, \mathrm{x} 5$, and $\mathrm{x} 6$. According to the statements of women who helped in realizing this research, the support of the $\boldsymbol{A E W s}$ in making their decision whether to establish their own enterprise or not participates with $54.76 \%$.

\section{Conclusion}

The women's empowerment in starting their own business in Sirinicka Zupa is mostly motivated by "self-employment and the care for their families". When it is about the business environment, the research has shown the series of its unfavourable conditions for the development of female entrepreneurship, as well as the opinion of women entrepreneurs that the environment has been unsuitable for female entrepreneurship. Along with unfavourable economic conditions, which follow the trends of delayed and difficult transition in Serbia, and few years ago the effects of the world economic crisis as well, as an aggravating circumstance for the women entrepreneurship has occurred also the significant gender inequalities, which have represented an obstacle when starting a business, as well as later, during the business development. That is why we are not surprised by the essentially unfavourable perception of business climate among women entrepreneurs, which can be noticed in the survey sample: $80 \%$ of women entrepreneurs considered that is hard to start a business in Sirinicka Zupa due to the inaccessibility of a financial capital.

Besides deficiencies in education, one of the hardest challenges many women face when they start/enlarge their business is to balance their business obligations with their responsibilities in households. Although the only way to overcome these problems is to share responsibilities among men and women in a household, it cannot be expected in a short time. Hence, the task of the women's empowerment in the women's associations is to show the positive examples of female entrepreneurship to members of a group, and 
the final goal of this empowerment is the women's self-employment and starting their own businesses, the decrease of unemployment, the employment on own holdings, and the self-sustainable development of Sirinicka Zupa and survival of the Serbian population in Kosovo and Metohija.

The conclusion can be drawn that the most important factors that affect the women's empowerment are: motives, business environment and support of the AEW. Nonetheless, this paper imposes a conclusion that the members of AEW are strongly empowered: the empowerment can be manifested in a form of starting a new business in the field of rural tourism and the production of agricultural products; as well the fact that the greatest significance of the AEW in the information-financial support. It has confirmed the main hypothesis $\mathrm{X}$ that self-employment is the final goal of the women's empowerment. This has produced a formula of the women's empowerment that has been also the final goal of this paper: self-employment as the final goal of women's empowerment depends directly from motives for starting an own enterprise $(25 \%)$, the environment business impacts (20.24\%), and the AEW support (54.76\%).

\section{Conflict of interests}

The authors declare no conflict of interest.

\section{References}

1. Ali, I., Hatta, A.Z. (2012): Women's Empowerment or Disempowerment through Microfinance: Evidence from Bangladesh. Asian Social Work and Policy Review 6, 111-121.

2. Agarwal, B. (1997): Bargaining and gender relations: within and beyond the household. Feminist Economics, 3(1), 1-51.

3. Ateljevic J. (2009): Tourism entrepreneurship and regional development: Example from New Zealand. International Journal of Entrepreneurial Behaviour and Research, 15(3), 282-308

4. Batliwala, S. (1994): The meaning of women's empowerment: New concepts from action, In G. Sen, A. Germain \& L. Chen (Eds.), Population policies reconsidered: Health, empowerment and rights. Cambridge MA: Harvard University Press.

5. Bhatt-Datta, P., Gailey, R. (2012): Empowering Women Through Social Entrepreneurship: Case Study of a Women's Cooperative in India. Entrepreneurship theory and practice, 36(3), 569-587.

6. Calás, M., Smircich, L., Bourne, K. (2009): Extending the boundaries: Reframing "entrepreneurship as social change" through feminist perspectives. Academy of Management Review, 34(3), 552-569.

7. Chessell, D. (2018). The Jobless Economy in a Post-Work Society: How Automation Will Transform the Labor Market. Psychosociological Issues in Human Resource Management, 6(2), 74-79. 
8. Dur, R., Glazer, A. (2008): The desire for impact. Journal of Economic Psychology, 29(3), 285-300.

9. De Bruin, A., Brush, C., Welter, F. (2006): Towards building cumulative knowledge on women's entrepreneurship. Entrepreneurship Theory and Practice, 30(5), 585594.

10. De Bruin, A., Brush, C., Welter, F. (2007): Advancing a framework for coherent research on women's entrepreneurship. Entrepreneurship Theory and Practice, 31(3), 323-339.

11. Eisenhardt, K.M., Graebner, M.E.(2007): Theory building from cases: Opportunities and challenges. Academy of Management Journal, 50, 25-32.

12. Floro-Maria, S. (1995): Economic restructuring, gender and the allocation of time. World Development, 23(11), 1913-1929.

13. Godwyn, M. (2009): This Place Makes Me Proud to be a Woman": Theoretical explanations for success in entrepreneurship education for low-income women. Research in Social Stratification and Mobility, 27, 50-64

14. González, S. M. (2018). What Do Consumers Appreciate about On-Demand Economy Workers?. Psychosociological Issues in Human Resource Management, 6(2), 29-43.

15. Grossman, T. (2018). The Rise of an Automated Jobless Society: Do Cutting-Edge Technologies Expel Workers Swifter than the Economy Can Identify New Jobs for Them?. Psychosociological Issues in Human Resource Management, 6(2), 62-67.

16. Heilman, E.M., Chen, J.J. (2003): Entrepreneurship as a solution: the allure of selfemployment for women and minorities. Human Resource Management Review, 13(2), 347-364

17. Harriet, B., Sen, G. (2003): Women's empowerment and demographic processes: Moving beyond Cairo. New York, NY: Oxford University Press.

18. Hania, U., Rachmaniaa, I.N., Setyaningsiha, S., Putria, R.C. (2012): Patterns of Indonesian Women Entrepreneurship. Procedia Economics and Finance 4, 274 285

19. Hashemi, S.M., Schuler, S.R. (1993): Defining and studying empowerment of women: A research note from Bangladesh. JSI Working Paper No. 3. Arlington, VA: JSI.

20. Hashemi, S.M., Schuler, S.R., Riley, A.P., (1996): Rural credit programs and women's empowerment in Bangladesh. World Development, 24(4), 635- 653.

21. Kabeer, N. (2005): Is Microfinance a 'Magic Bullet'for. Women's Empowerment: Analysis of Findings from. South Asia. Economic and Political Weekly, 40(44): 4709-4718.

22. Markantoni, M., Van Hoven, B. (2012): Bringing 'invisible' side activities to light. A case study of rural female entrepreneurs in the Veenkoloniën, the Netherlands. Journal of Rural Studies, 28, 507-516 
23. Mosedale, S. (2005): Assessing women's empowerment: towards a conceptual framework. Journal of International Development, 17, 243-257.

24. Moser, C. (1991): Gender planning in the Third World: Meeting practical and strategic gender needs. In T. Wallace, C. March (eds.) Changing Perspectives: Writings on Gender and Development, Oxford: Oxfam.

25. Narayan, D., (Ed.) (2002): Empowerment and Poverty Reduction: A Sourcebook. Washington, DC: World Bank.

26. Orser, J.B., Riding, L.A., Manley, K. (2006): Women Entrepreneurs and Financial Capital. Entrepreneurship Theory and Practice, 30(5), 643-655.

27. Osirim, J.M. (2001): Making good on commitments to Grassroots Women: NGO's And Empowerment for women In Contemporary Zimbabwe. Women's Studies International Forum, 24(2), 167-180.

28. Petrović, M., Blešić, I., Vujko, A., Gajić, T. (2017): The role of agritourism impact on local community in a transitional society: a report from Serbia. Transylvanian Review of Administrative Sciences, 50/2017, 146-163.

29. Ramanathan, M. (2004): Women and empowerment: Shri Mahila Griha Udyog Lijjat Papad. Economic and Political Weekly, 39(17), 1689-1697.

30. Rao, S. (2011): Work and Empowerment: Women and Agriculture in South India. Journal of Development Studies, Vol. 47, No. 2, 294-315

31. Reddy, S., Galab, S., Rao, P. (2003): Trends and determinants of poverty: 1973 to 1999-2000. Economic and Political Weekly, 38(12-13), 1262-1274.

32. Swanson, K.K., Timothy, J.D. (2012): Souvenirs: Icons of meaning, commercialization and commoditization. Tourism Management, 33(3), 489-499

33. Shabbir, A., di Gregorio, S. (1996): An examination of the relationship between women's personal goals and structural factors influencing their decision to start a business: The case of Pakistan. Journal of Business Venturing, 11(6), 507-529.

34. Seguino, S. (2000): Gender inequality and economic growth: a cross-country analysis. World Development, 28(7), 1211-1230.

35. Soroushmehr, H.,Kalantari, K., Fami, H.S., Sarani, V. (2012): Investigation of Selfhelp Groups (SHGs) Effect on Rural Women Empowerment (Hamedan County, Iran). Journal of Agricultural Science, 4(1), 1-13

36. Sorells, B. (2018). Will Robotization Really Cause Technological Unemployment? The Rate and Extent of Potential Job Displacement Caused by Workplace Automation. Psychosociological Issues in Human Resource Management, 6(2), 68-73.

37. Šapić, S., Furtula, S., \& Durkalić, D. (2018). Prestige and national identity as predictors of food products purchase. Economics of Agriculture, 65(2), 643-657.

38. Tassel, E.V. (2004): Household bargaining and microfinance. Journal of Development Economics, 74, 449-468. 
39. Vujko, A., Petrović, M., Dragosavac, M., Gajić, T., (2016): Differences and similarities among rural tourism in Slovenia and Serbia - perceptions of local tourism workers. Ekonomika poljoprivrede, 63(4)/2016, 1459-1469.

40. Vujko, A., Gajić, T., Dragosavac, M., Maksimović, B., Mrkša, M. (2017): Level of integration among rural accommodation sector and travel agencies. Ekonomika poljoprivrede 64(2)/2017, 659-670

41. Vujko,A., Maksimović,G. (2018): Empowerment of women's status in the rural surroundings through self-employement, Sustainable agriculture and rural development in terms of the Republic of Serbia strategic goals realization within the danube region, Institute of agricultural economics, Belgrade, Serbia. ISBN 97886-6269-061-6 COBISS.SR-ID 257428748 pages:1-18 